\title{
Keadilan Ekonomi dalam Perspektif Ekonomi Syariah: Sebuah Tinjauan Teori
}

\author{
Suryani \\ Dosen Jurusan Syariah Prodi Ekonomi Islam \\ STAIN Malikussaleh Lhokseumawe \\ suryapijar@yahoo.com
}

\begin{abstract}
Abstrak:
Manusia telah diciptakan untuk menangani bumi ini untuk mencapai kemakmuran dan kebahagiaannya, dengan tidak boleh mengambil tindakan yang lain kecuali untuk menegakkan keadilan. Islam menghendaki supaya keadilan itu dapat dicapai dalam segala aspek hidup, termasuk politik, ekonomi, sosial, dan budaya.

Komitmen Islam yang besar pada persaudaraan dan keadilan, menuntut agar semua sumber daya dimafaatkan untuk mewujudkan maqashid syari'ah, yakni pemenuhan kebutuhan hidup manusia, terutama kebutuhan dasar (primer), seperti sandang, pangan, papan, pendidikan dan kesehatan. Persaudaraan dan keadilan juga menuntut agar sumberdaya didistribusikan secara adil kepada seluruh rakyat melalui kebijakan yang adil melalui instrumen zakat, infaq, sedekah, pajak, kharaj, jizyah, cukai ekspor-impor dan sebagainya.

Konsep keadilan sosio ekonomi dalam Islam berbeda secara mendasar dengan konsep keadilan dalam kapitalisme dan sosialisme. Keadilan sosio ekonomi dalam Islam, selain didasarkan pada komitmen spritual, juga didasarkan atas konsep persaudaraan universal sesama manusia.
\end{abstract}

Keyword: keadilan, ekonomi, zakat. 


\title{
Economic Justice in the Islamic Economic Perspective: \\ a Literature Review
}

\author{
Suryani \\ Lecturer in Islamic Economic, Sharia Department \\ in STAIN Malikussaleh Lhokseumawe - Aceh \\ suryapijar@yahoo.com
}

\begin{abstract}
:
Humans were created to organize this world in order to achieve prosperity and happiness. Man can not take any action except to uphold fairness. Islam wants fairness is achieved in every aspect of life, including political, economic, social, and cultural.

Major commitment of Islam to brotherhood and fairness is the demand that all resources can beutilized to realize maqasid sharia, the fulfillment of human needs, especially basic necessities, such as food, clothing, shelter, education and health. Brotherhood and fairness demands that resources are distributed fairly among all the people through fair policy through instruments such as zakat, infaq, charity, tax kharaj, jizya, the export-import clearance and so on.

Thus, the concept of socio-economic fairness in Islam is fundamentally different to the concept of fairness in capitalism and socialism. Socio-economic fairness in Islam, rather than being based on spiritual commitment, is also based on the concept of universal brotherhood of humanity.
\end{abstract}

Keyword: fairness, economic, zakat. 


\section{PENDAHULUAN}

Masalah ekonomi tidak dapat dipisahkan dari kehidupan manusia. Ia berkaitan dengan berbagai macam kebutuhan, seperti kebutuhan pangan, sandang dan papan, serta kebutuhan lainnya. Untuk memenuhi kebutuhan hidup, sudah seharusnya manusia bekerja dengan mengolah segala yang telah disediakan di alam semesta ini, dan dari hasil kebutuhan tersebut kebutuhan manusia dapat terpenuhi, baik kebutuhan primer, sekunder, dan tertier.

Manusia telah diciptakan untuk menangani bumi ini bagi mencapai kemakmuran dan kebahagiaannya dengan tidak boleh mengambil tindakan yang lain kecuali untuk menegakkan keadilan. Islam menghendaki supaya keadilan itu dapat dicapai dalam segala aspek hidup, termasuk kehakiman, politik, ekonomi, sosial, dan budaya. Dengan demikian, hendaknya manusia memandang sesuatu yang merupakan kebutuhan itu, merupakan hal yang diperlukan untuk menyempurnakan pengabdiannya kepada Allah SWT.

Dalam perspektif Islam, bahwasanya kebijakan ekonomi berarti suatu sistem pengaturan yang sanggup mengembangkan kehidupan ekonomi masyarakat yang wajar dan adil ${ }^{1}$. Kebijaksanaan ekonomi dalam Islam harus mensejahterakan kehidupan masyarakat, melalui perangkat-perangkat mekanisme yang lengkap, dan dapat dibedakan dari perekonomian sistem lainnya, yang sudah kita kenal di dunia pada saat sekarang ini yakni kapitalisme dan sosialisme, yang masing-masing bersaing untuk berusaha menguasai perekonomian dunia dan merupakan rujukan dalam penyelesaian masalah ekonomi.

Sebenarnya, Islam telah menawarkan dan merealisasikan konsep sistem pemeliharaan dan pengaturan urusan rakyat, cara pemenuhan kebutuhan pokok bagi warga masyakat, cara penanganan kemiskinan, perwujudan kesejahteraan hidup, dan lain sebagainya. Islam tidak berangkat dari keprihatinan sosial, yang bersifat nisbi dan kondisional atau berpijak diatas dasar nilai-nilai sosial dan kemanusiaan semata. Ekonomi Islam sebagai sebuah aturan (nizam) yang dapat

1 Muhammad Baqir Shadr, Ekonomi Islam : Khayalan atau Kenyataan?, Yayasan Muthahhari 
memecahkan problematika kehidupan manusia, yang bertitik tolak dari pandangan dasar tentang manusia dan kehidupan ini (aqidah $)^{2}$.

Keadilan merupakan pilar terpenting dalam ekonomi Islam. Penegakan keadilan telah ditekankan oleh al-Qur'an sebagai misi utama para Nabi yang diutus Allah (QS. 57:25), termasuk penegakan keadilan ekonomi dan penghapusan kesenjangan pendapatan ${ }^{3}$.

Allah yang menurunkan Islam sebagai sistem kehidupan bagi seluruh umat manusia, menekankan pentingnya penegakan keadilan dalam setiap sektor, baik ekonomi, politik maupun sosial. Komitmen al-Qur'an tentang penegakan keadilan sangat jelas. Hal itu terlihat dari penyebutan kata keadilan di dalam al-Qur'an mencapai lebih dari seribu kali ${ }^{4}$ yang berarti; kata urutan ketiga yang banyak disebut al-Qur' an setelah kata Allah dan 'Ilm.

Bahkan, Ali Syariati menyebutkan, dua pertiga ayat-ayat al-Qur'an berisi tentang keharusan menegakkan keadilan dan membenci kezhaliman, dengan ungkapan kata zhulm, itsm, dhalal, dan lain-lain ${ }^{5}$. Karena itu, tujuan keadilan sosio ekonomi dan pemerataan pendapatan/kesejahteraan, dianggap sebagai bagian tak terpisahkan dari filsafat moral Islam.

Begitulah, penekanan Islam pada penegakan keadilan sosio ekonomi. Maka, adalah keliru, klaim kapitalis maupun sosialis yang menyatakan, "Hanya ideologi kami yang berbicara dan bertindak tegas dalam masalah keadilan. "Setidaknya hanya kamilah yang mempunyai komitmen kuat tentang nilai-nilai keadilan”. Itulah klaim yang dilontarkan berbagai komponen masyarakat dunia dalam kerangka memperlihatkan keunggulan ideologi atau kepercayaan yang mereka anut.

Hanya saja kegiatan perbankan dan keuangan syari'âh ini masih belum sepenuhnya terlepas dari pengaruh sistem ekonomi konvensional (baca: ekonomi liberal) yang telah bercokol cukup lama di negeri ini. Oleh karena itu diperlukan

2 http://www.hayatulislam.net. diakses 23 Januari 2013.

3 http://isjd.pdii.lipi.go.id/admin/jurnal/81081732.pdf Peran Lembaga Keuangan Publik Islam, diakses 23 Januari 2013.

4 Penyebutan kata keadilan dalam al-Qur'an tidak saja menggunakan akar kata 'adil tetapi juga al-mizan dan al-qist.

Majid Kahduri, The Islamic Conception of Justice, (1984), h. 10. 
kemauan dan tekad kuat untuk memurnikan kegiatan ekonomi Islam dari unsurunsur yang bertentangan dan berlawanan dengan prinsip ajaran Islam (al-Qur'an dan Hadits).

Harus kita bedakan bahwa konsep kapitalis tentang keadilan sosio ekonomi dan pemerataan pendapatan, tidak didasarkan pada komitmen spiritual dan persaudaraan (ukhuwah) sesama manusia. Komitmen penegakan keadilan sosio ekonomi lebih merupakan akibat dari tekanan kelompok. Karenanya, sistem kapitalisme terutama yang berkaitan dengan uang dan perbankan, tidak dimaksudkan untuk mencapai tujuan-tujuan keadilan sosio ekonomi yang berdasarkan nilai transendental (spritual) dan persaudaraan universal. Sehingga, tidak aneh, apabila uang masyarakat yang ditarik oleh bank konvensional (kapitalis) dominan hanya digunakan oleh para pengusaha besar (konglomerat). Lembaga perbankan tidak dinikmati oleh rakyat kecil yang menjadi mayoritas penduduk sebuah negara. Fenomena ini semakin jelas terjadi di Indonesia. Akibatnya yang kaya semakin kaya dan miskin makin miskin. Ketidakadilan pun semakin lebar.

Sebagaimana disebut di atas, konversi ekonomi Barat (terutama kapitalisme) kepada penegakan keadilan sosio ekonomi, merupakan akibat tekanan-tekanan kelompok masyarakat dan tekanan-tekanan politik. Untuk mewujudkan keadilan sosio-ekonomi itu mereka mengambil beberapa langkah, terutama melalui pajak dan transfer payment.

Meskipun ada usaha melalui instrumen pajak, namun langkah-langkah ini menurut Milton Friedman, terbukti tidak cukup efektif untuk mengatasi ketidakadilan, karena nyatanya pajak selalu menguntungkan pengusaha, dan para pejabat pajak bersama kelompok-kelompoknya ${ }^{6}$.

Jadi, konsep keadilan sosio ekonomi dalam Islam berbeda secara mendasar dengan konsep keadilan dalam kapitalisme dan sosialisme. Keadilan sosio ekonomi dalam Islam, selain didasarkan pada komitmen spritual, juga didasarkan atas konsep persaudaraan universal sesama manusia.

6 Lihat, “Capitalisme and Freedom”, Chicago, The University of Chicago Press, 1962, p.172. 
Al-Qur'an secara eksplisit menekankan pentingnya keadilan dan persaudaraan tersebut. Menurut M. Umer Chapra, sebuah masyarakat Islam yang ideal mesti mengaktualisasikan keduanya secara bersamaan, karena keduanya merupakan dua sisi yang sama yang tak bisa dipisahkan. Dengan demikian, kedua tujuan ini terintegrasi sangat kuat ke dalam ajaran Islam sehingga realisasinya menjadi komitmen spritual (ibadah) bagi masyarakat Islam.

Komitmen Islam yang besar pada persaudaraan dan keadilan, menuntut agar semua sumber daya dimafaatkan untuk mewujudkan maqashid syari'ah, yakni pemenuhan kebutuhan hidup manusia, terutama kebutuhan dasar (primer), seperti sandang, pangan, papan, pendidikan dan kesehatan. Persaudaraan dan keadilan juga menuntut agar sumberdaya didistribusikan secara adil kepada seluruh rakyat melalui kebijakan yang adil dan instrumen zakat, infaq, shadakah, pajak, kharaj, jizyah, cukai ekspor-impor dan sebagainya.

Tauhid yang menjadi fondasi utama ekonomi Islam, mempunyai hubungan kuat dengan konsep keadilan sosio-ekonomi dan persaudaraan. Ekonomi Tauhid yang mengajarkan bahwa Allah sebagai pemilik mutlak dan manusia hanyalah sebagai pemegang amanah, mempunyai konsekuensi, bahwa di dalam harta yang dimiliki setiap individu terdapat hak-hak orang lain yang harus dikeluarkan sesuai dengan perintah Allah, berupa zakat, infaq dan sedekah dan cara-cara lain untuk melaksanakan pendistribusian pendapatan yang sesuai dengan konsep persaudaraan umat manusia.

Sistem keuangan dan perbankan serta kebijakan moneter, misalnya, dirancang semuanya secara organis dan terkait satu sama lain untuk memberikan sumbangan yang positif bagi pengurangan ketidakadilan dalam ekonomi dalam bentuk pengucuran pembiayaan (kredit) bagi masyarakat dan memberikan pinjaman lunak bagi masyarakat ekonomi lemah melalui produk qardhul hasan. Al-Quran dengan tegas mengatakan, "Supaya harta itu tidak beredar di kalangan orang kaya saja di antara kamu" (QS. 59:7), "Di antara harta mereka terdapat hak fakir miskin, baik peminta-minta maupun yang orang miskin malu memintaminta" (QS. 70:24). 
Karena itu, Islam menekankan keseimbangan antara petumbuhan dan pemerataan. Pertumbuhan an sich bukan menjadi tujuan utama, kecuali dibarengi dengan pemerataan. Dalam konsep Islam, pertumbuhan dan pemerataan merupakan dua sisi dari sebuah entitas yang tak terpisahkan, karena itu keduanya tak boleh dipisahkan.

Berdasarkan prinsip ini, maka paradigma tricle down effect, yang dikembangkan kapitalisme dan pernah diterapkan di Indonesia selama rezim orde baru, bertentangan dengan konsep keadilan ekonomi menurut Islam.

Selanjutnya, sistem ekonomi kapitalis dicirikan oleh menonjolnya peran perusahaan swasta (private ownership) dengan motivasi mencari keuntungan maksimum, harga pasar akan mengatur alokasi sumberdaya, dan efisiensi. Namun sistem ini selalu gagal dalam membuat pertumbuhan dan pemerataan berjalan dengan seiring.

Sistem ekonomi kapitalis telah menggoyahkan fondasi moral manusia, karena sistem ini telah menghasilkan manusia yang tamak, boros dan angkuh. Sistem kapitalis juga telah melahirkan sejumlah bankir hebat, beberapa industriawan yang kaya raya, sejumlah pengusaha yang sukses. Namun di pihak lain, telah muncul banyak konsumen yang tidak mampu memenuhi kebutuhan minimumnya. Kesenjangan terjadi secara tajam.

Perlu ditegaskan, bahwa melekatnya hak orang lain pada harta seseorang (QS. 70:24), bukanlah dimaksudkan untuk mematahkan semangat karya pada setiap individu atau menimbulkan rasa malas bagi sebagian orang. Juga tidak dimaksudkan untuk menciptakan pemerataan pemilikan kekayaan secara kaku.

Dalam perspektif ekonomi Islam, proporsi pemerataan yang betul-betul sama rata, sebagaimana dalam sosialisme, bukanlah keadilan, malah justru dipandang sebagai ketidakadilan. Sebab Islam menghargai prestasi, etos kerja dan kemampuan seseorang dibanding orang yang malas.

Dasar dari sikap yang koperatif ini tidak terlepas dari prinsip Islam yang menilai perbedaan pendapatan sebagai sebuah sunnatullah. Landasannya, antara lain bahwa etos kerja dan kemampuan seseorang harus dihargai dibanding seorang pemalas atau yang tidak mampu berusaha. Bentuk penghargaannya adalah sikap 
Islam yang memperkenankan pendapatan seseorang berbeda dengan orang lain, karena usaha dan ikhtiarnya. Firman Allah,

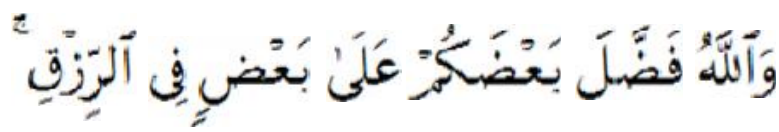

Artinya: "Sesungguhnya Allah melebihkan rezeki sebagian kamu atas sebagian lain". (QS. 16:71).

Namun, orang yang diberi kelebihan rezeki, harus mengeluarkan sebagian hartanya untuk kelompok masyarakat yang tidak mampu (dhu'afa). Sehingga seluruh masyarakat terlepas dari kemisikinan.

Konsep keadilan sosio-ekonomi yang diajarkan Islam menginginkan adanya pemerataan pendapatan secara proporsional. Dalam tataran ini, dapat pula dikatakan bahwa ekonomi Islam adalah ekonomi yang dilandaskan pada kebersamaan. Karena itu tidak aneh, jika anggapan yang menyatakan bahwa prinsip keadilan sosio-ekonomi Islam mempunyai kemiripan dengan sistem sosialisme. Bahkan pernah ada pendapat yang menyatakan bahwa sistem sosialisme itu jika ditambahkan dan dimasukkan unsur-unsur Islam ke dalamnya, maka ia menjadi islami.

Dengan demikian, pendapat dan pandangan yang menyatakan kemiripan sistem keadilan sosio Islam dengan sosialisme tidak sepenuhnya benar, malah lebih banyak kekeliruannya. Prinsip ekonomi sosialisme, yang menolak kepemilikan individu dan menginginkan pemerataan pendapatan, jelas berbeda dengan prinsip ekonomi Islam. Sosialisme sama sekali tidak mengakui hak milik individu.

Reaksi marxisme dibungkus secara politis revolusioner dalam paham komunis yang intinya mengajarkan bahwa seluruh unit ekonomi dikuasakan kepada negara yang selanjutnya didistribusikan kepada seluruh masyarakat secara merata. Hal ini didasarkan semangat pertentangan terhadap kepemilikan individu.

Sedangkan dalam ekonomi Islam, penegakan keadilan sosio-ekonomi dilandasi oleh rasa persaudaraan (ukhuwah), saling mencintai (mahabbah), bahumembahu (takaful) dan saling tolong-menolong (ta'awun), baik antara si kaya dan si miskin maupun antara penguasa dan rakyat. 
Pada dasarnya ekonomi Islam yang merupakan sistem ekonomi syari'âh itu berdiri tegak pada azas-azas kebersamaan dan keadilan dalam mencapai tujuan. Paling tidak terdapat empat prinsip yang melandasi praktik ekonomi Islam.

Pertama; anjuran membelanjakan harta di jalan Allah semaksimal mungkin untuk tercapainya keadilan dan kesejahteraan sosial. Malalui prinsip ini kemudian terejawantahkan konsep zakat, sedekah, infak, wakaf dan sebagainya. Pada dasarnya Islam tidak mentolerir terjadinya kesenjangan mencolok antara kaum the have dengan kalangan the have not.

Kedua; larangan untuk melakukan riba. Para ulama memang terpecah pendapat dalam menyikapi apakah bunga bank termasuk riba. Namun demikian pada dasarnya mereka sama-sama sepakat bahwa apabila ada dua orang melakukan transaksi (bisnis) tidak boleh ada salah seorang diperlakukan "kalah" sehingga muncul skema win-lose, salah seorang menderita kerugian dari pada yang lain. Sehingga muncul ketidakadilan dalam menanggung resiko.

Lalu muncul prinsip ketiga; membagi resiko bersama (risk sharing). Jika suatu usaha yang dikelola bersama mengalami kerugian maka para pihak dapat menanggung resiko secara bersama-sama secara adil dan bijaksana, tidak boleh salah satu pihak merasa tidak puas karena didzholimi.

Terkait prinsip ketiga maka terdapat prinsip keempat yaitu melarang terjadinya eksploitasi dari satu manusia pada manusia lainnya. Artinya, salah satu pihak yang bersepakat untuk suatu usaha (bisnis) tidak boleh menjadi kaya sendiri sementara pihak lain dalam situasi menderita. Dalam konteks ini maka pembagian keuntungan yang berat sebelah dalam suatu kontrak karya (proyek bisnis) misalnya bisa disebut sebagai kontrak karya yang bertentangan dengan prinsip ajaran Islam.

Prinsip kelima adalah larangan melakukan usaha yang bersifat spekulasi. Contoh kongkrit adalah judi. Setiap usaha telah ditelaah, direncanakan matang, tertata baik dan logis, lalu prediksi dan antisipasi dilakukan sesuai prinsip rasionalitas bukan didasarkan perilaku spekulatif yang nir data dan informasi tidak akurat. Prinsip ini merupakan pengejawantahan manajemen modern. Namun manusia acapkali serakah dan amoral yang membuat prinsip diatas terabaikan. 
Pada masa kejayaan Islam dimana penguasa memperhatikan kehidupan dan kesejahteraan masyarakat dengan penegakan prinsip keadilan ditegakkan, tauhid sosial juga dipraktikkan melalui kepedulian terhadap kaum papa dan lemah. Jaminan dan solidaritas sosial yang dibangun dari prinsip Islam yakni mengoptimalkan peran dan fungsi zakat mampu menjembatani kesenjangan si kaya dan si miskin ${ }^{7}$.

Sistem ekonomi Islam merupakan sistem ekonomi yang lahir dari sistem sosial islami yang diharapkan dapat memberikan solusi terhadap berbagai permasalahan yang ada dengan kebijakan-kebijakan yang berpihak kepada kemaslahatan dan keadilan dalam ekonomi umat. Kebijakan distribusi dalam Sistem ekonomi Islam menjunjung tinggi nilai keadilan yang didasarkan pada konsep distribusi dalam al-Qur' an surah al-Hashr "agar kekayaan tidak terkumpul hanya pada satu kelompok saja." Menurut Quraish Shihab, ayat tersebut bermaksud untuk menegaskan bahwa harta benda hendaknya jangan hanya menjadi milik dan kekuasaan sekelompok manusia. Harta benda harus beredar di masyarakat sehingga dapat dinikmati oleh semua anggota masyarakat dengan tetap mengakui hak kepemilikan dan melarang monopoli, karena sejak awal Islam menetapkan bahwa harta memiliki fungsi sosial ${ }^{8}$.

Berdasarkan ayat di atas, ekonomi Islam tidak membenarkan penumpukan kekayaan hanya pada orang-orang tertentu atau kelompok tertentu. Bahkan menggariskan prinsip keadilan dan persaudaraan (kasih sayang) pada konsep distribusinya. Pengelolaan kekayaan tidak dibenarkan hanya berpihak pada golongan atau sekelompok orang tertentu tetapi juga harus tersebar ke seluruh masyarakat. Sebaliknya Islam pun tidak memaksa semua individu diletakkan pada tingkat ekonomi yang sama 9 .

Tulisan ini memfokuskan pada bahasan keadilan ekonomi dalam perpestif ekonomi syariah.

\footnotetext{
Ruslan Abdul Ghofur Noor, Kebijakan Distribusi Ekonomi Islam Dalam Membangun Keadilan Ekonomi Indonesia, Islamica, Vol. 6, No. 2, Maret 2012, h. 318.

8 M. Quraish Shihab, Tafsir al-Mishbah, Vol. 14, (Jakarta: Lentera Hati, 2002), h. 112-113.

9 Afzalur Rahman, Ecnomic Doktrines of Islam, terj. Soeroyo et al. (Yogyakarta: Dhana Bakti Wakaf, 1995), h. 12.
} 


\section{PEMBAHASAN}

\section{KONSEP KEADILAN DALAM AL-QUR'AN}

Diantara term-term penting yang berkaitan dengan moral yang diungkapkan oleh al-Qur'an adalah keadilan ${ }^{10}$. Ini terlihat dari banyaknya kata 'adl (justice, keadilan) dan kata-kata yang semakna seperti al-qist, al-wazn, alwast yang terdapat dalam berbagai tempat dalam al-Qur'an. Selain dari ungkapanungkapan yang secara eksplisit menyebut kata $a l$-adl, sebenarnya pada ayat-ayat yang paling awal, ide dan pikiran tentang keadilan telah datang secara bersamaan $^{11}$. Tidak itu saja perintah berbuat adil juga terlihat dari larangan alQur'an berbuat zalim. Tidaklah berlebihan apabila Fazlur Rahman seorang pemikir Islam kontemporer menyatakan bahwa, pesan dasar al-Qur'an adalah penekanan pada keadilan yang salah satu bentuknya terlihat pada keadilan sosial ekonomi ${ }^{12}$.

Dalam al-Qur'an term-term $a l$ - 'adl dengan berbagai derivasinya disebut sebanyak 30 kali $^{13}$. Arti pokok dari kata ini mengandung dua makna yang berlawanan (mutaqabilain), pertama makna istiwa' (lurus) dan kedua makna i’wijaj (bengkok). Di samping kata 'adl terdapat kata yang semakna seperti al-qist dengan segala bentuknya disebut sebanyak 23 kali. Kata yang tersusun dari $q-s-t$ mengandung dua makna yang berlainan (mutadaddidain). Kalau ia di baca al-qist, maka ia berarti al-'adl, sementara kalau dibaca al-qast, maka maknanya al-jurr, dan al-qusut berarti al-udud an al-haq (berpaling dari kebenaran) dan al-qasat bermakna $i$ 'wijaj (bengkok) ${ }^{14}$. Selain kata al-wazn dengan segala turunannya sebanyak $23 \mathrm{kali}^{15}$. Arti pokoknya adalah ta'dil dan istiqomah (moderat dan

10 Mawardi, Konsep Al- 'Adalah Dalam Perspektif Ekonomi Islam, Hukum Islam. Vol. VII No. 5. Juli 2007, h. 547-551.

11 Fazlur Rahman, Islam and Modernity, Transformation of Intellectual Tradition, (Chicago: The University of Chicago Press, 1982), h. 21.

12 Ibid

13 Muhammad Fu'ad Abdul Baqi, al-Mu "jam al-Mufahras li alfazd Al-Qur'an al-Karim, (Mesir: Dar al-Fikr, 1981), h. 448.

14 Dalam al-Qur'an penggunaan kata al-qist mengacu pada keadilan hukum seperti yang terdapat pada QS. al-Maidah : 42. Firman Allah SWT.......dan jika kamu memutuskan perkara mereka, maka putuskan diantara mereka dengan adil (al-qist), sesungguhnya Allah SWT menyukai orang-orang yang adil, (muqsitin).

15 Muhammad Fu'ad Abd al-Baqiy, Op.cit, h. 750. 
lurus). Sedangkan kata al-wast diungkapkan al-Qur'an sebanyak 5 kali yang arti aslinya adalah $a l$ - 'adl dan al-nisf, tengah atau pusat. ${ }^{16}$

Memahami sebuah konsep dalam al-Qur'an tidaklah utuh jika penelusuran makna hanya dilakukan pada tema pokok dan tema yang semakna. Agaknya diperlukan untuk menelusuri kontra (lawan kata) dari tema pokok tersebut. Sampai di sini memahami kontra ' $a d l$ menjadi satu kemestian. Didalam al-Qur'an kata ' $a d l$ selalu dihadapkan dengan kata zalm. ${ }^{17}$ Seringkali ketika Allah memerintahkan berbuat adil pada saat yang sama Allah melarang untuk bersikap zalim. Kata al-zulm bermakna meletakkan sesuatu pada tempatnya yang semestinya, baik dengan cara melebihkan atau mengurangi maupun menyimpang dari waktu dan tempatnya. ${ }^{18}$ Melalui pendekatan tafsir maudhu'i (tematik) ditemukan bahwa konsep keadilan dalam al-Qur'an mengandung makna yang serba melingkupi. Pengertian keadilan itu berkisar pada makna perimbangan atau keadaan seimbang atau tidak ekstrim, persamaan atau tidak adanya diskriminasi dalam bentuk apapun, dan penunaian hak kepada siapa saja yang berhak atau penempatan sesuatu pada tempat yang semestinya. ${ }^{19}$

Pengertian-pengertian yang terkandung dalam konsep keadilan ini sudah barang tentu mempunyai implikasi terhadap aktivitas dan perilaku manusia. Implikasi itu terlihat pada keadilan hukum dalam makna bahwa al-Qur'an memerintahkan agar manusia memperlakukan semua orang sama dihadapan hukum dan tidak boleh membedakannya berdasarkan aksiden-aksiden (hal-hal yang melekat secara lahiriyah) yang dimilikinya.

Menegakan hukum secara adil merupakan perintah Tuhan yang sangat penting seperti termuat dalam surat an-Nisa' ayat 58 :

\footnotetext{
16 Ada kesan penggunaan kata al-wazn, khususnya yang diturunkan di Mekah berkaitan dengan pentingnya menegakkan keadilan dalam aktivitas ekonomi, seperti yang terlihat pada QS. alMuthaffifin: $1-3$.

17 Penjelasan kata adil dan zulm dapat dilihat pada M. Dawam Raharjo, Ensiklopedi al-Qur'an: Tafsir Sosial Berdasarkan Konsep-konsep Kunci, (Jakarta: Paramadina, 1996), h. 391-410.

18 Ibid, h. 326.

19 Amiur Nuruddin, Konsep Keadilan Dalam Al-Qur'an dan Implikasinya Pada Tanggung Jawab Moral, Disertasi pada Program Pascasarjana IAIN Sunan Kalijaga, (Yogyakarta, 1994), h. 63.
} 


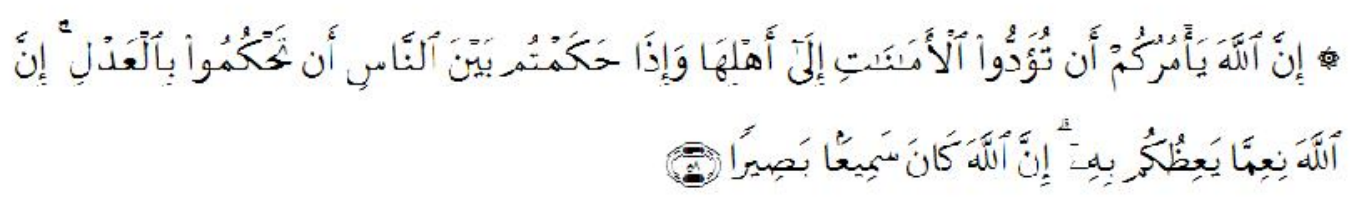

Artinya: "Sesungguhnya Allah menyuruh kamu menyampaikan amanat kepada yang berhak menerimanya, dan menyuruh kamu jika menetapkan hukum di antara manusia, hendaknya kamu menerapkannya secara adil”.

Dengan demikian keadilan hukum tidak akan membedakan orang berdasarkan status sosial yang dimilikinya, baik ia kaya atau miskin, pejabat atau rakyat biasa, terpelajar atau orang awam, dan tidak pula perbedaan warna kulit atau perbedaan bangsa dan agama, karena dihadapan hukum semuanya adalah sama. Konsep persamaan ini tidaklah menyingkirkan adanya pengakuan tentang kelebihan, yang dapat melebihkan seseorang karena prestasi yang dimilikinya, akan tetapi kelebihan itu tidak boleh membawa pada perbedaan perlakuan atau penerapan hukum pada dirinya. ${ }^{20}$

Dalam satu hadis Rasulullah SAW menyatakan: "Sesungguhnya Allah telah membinasakan orang-orang sebelum kamu, karena mengambil sikap, apabila yang melakukan pencarian orang telah terkemuka di kalangan mereka membiarkannya, sementara jika yang mencuri orang yang lemah (biasa) mereka menegakkan hukum atas orang tersebut. Dan sesungguhnya aku demi Allah, sekiranya Fatimah binti Muhammad melakukan pencarian, niscaya aku akan potong tangannya.",21

Keadilan dalam hubungan antar golongan mengandung arti bahwa alQur'an memberikan tuntunan moral agar manusia dapat hidup berdampingan secara damai dan bersahabat dengan orang lain walaupun berbeda suku, agama, dan ras. Ini berpihak pada semangat universal al-Qur'an sebagai rahmat bagi semua orang (rahmatan lilalamin).

20 Tentang persamaan hukum ini telah dicontohkan Rasulullah SAW dengan baik sekali yang selanjutnya diikuti oleh sahabat-sahabatnya.

21 Melalui Hadits ini sebenarnya Rasulullah SAW ingin menunjukkan komitmennya untuk menegakkan hukum tanpa membeda-bedakan obyeknya, walaupun yang terkena hukuman itu adalah keluarganya sendiri. 
Sedangkan keadilan ekonomi (economic justice) seperti yang terlihat nanti-mengandung pengertian bahwa al-Qur'an sangat menekankan persamaan manusia (egalitarianism) dan menghindarkan segala bentuk kepincangan sosial yang berpangkal dari kepincangan ekonomi, seperti eksploitasi, keserakahan, konsentrasi harta pada segelintir orang dan lain sebagainya. ${ }^{22}$ Tegasnya manusia dihadapan Allah SWT memiliki derajat yang sama, tanpa ada yang boleh merasa lebih mulia dari yang lain.

Kesadaran setara dihadapan Allah ini harus menjadi kesadaran internal bagi setiap manusia untuk berwawasan egalitarian (al-musawah) dengan tidak membeda-bedakan orang berdasarkan primordial yang dimilikinya seperti ras, agama, dan suku. Manusia hanya bisa diperlakukan secara berbeda hanya berdasarkan kualitas-kualitas objektif yang dimilikinya atau berdasarkan perbuatan-perbuatan yang dilakukannya. Wawasan terhadap manusia yang seperti inilah yang memungkinkan keadilan sosial-ekonomi dapat ditegakkan.

\section{Definisi Ilmu Ekonomi Islam}

Banyak beragam pendapat yang mengutarakan definisi tentang ekonomi Islam. Muhammad Abduh al-Arabi memaknai ekonomi Islam merupakan sekumpulan dasar-dasar umum ekonomi yang disimpulkan dari al-Qur'an dan Hadits dan merupakan bangunan perekonomian yang didirikan atas landasan dasar-dasar tersebut dengan lingkungan dan masanya ${ }^{23}$.

Secara definitif, ekonomi Islam didefinisikan sebagai:

"Islamic economics aims the study of the human falah (well-being) achieved by organizing the resourches of the earth on the basic of cooperation and participation".

22 Dengan demikian konsep keadilan sosial-ekonomi dalam perspektif Islam didasarkan pada ajaran persaudaraan yang melampaui batas-batas geografis seperti yang dicanangkan oleh alQur'an (QS. al-Hujarat: 13 dan al-Maidah: 8).

23 Ahmad Muhammad al-'Assal dan Fathi Ahmad Abdul Karim, Sistem, Prinsip, dan Tujuan Ekonomi Islam, Terj. Imam Saefudin (Bandung: Pustaka Setia, 1999), h. 17. 
Definisi yang diajukan M. Akram Khan ini merefer pada kajian tentang kebahagiaan manusia (dunia dan akhirat) yang akan dicapai dengan menggunakan sumber daya alam. ${ }^{24}$ M. Umer Chapra mendefinisikan ekonomi syari’ âh dengan:

"Islamic economics was defined as that branch of knowledge which helps realize human well-being through an allocation and distribution of scarce resources that is in confirmity with Islamic teaching without unduly curbing individual freedom or creating continued macro economic and ecological imbalances".

Jadi, menurut Chapra, ekonomi syari'âh adalah sebentuk pengetahuan yang membantu upaya realisasi kebahagiaan manusia melalui alokasi dan distribusi sumber daya yang terbatas dalam koridor ajaran Islam tanpa memberikan kebebasan individu atau tanpa prilaku makro ekonomi yang berkesinambungan dan tanpa ketidakseimbangan lingkungan ${ }^{25}$. Kursyid Ahmad memberikan definisi ekonomi syari' âh, sebagai "is a systematic effort to thy to understand the economic's problem and man's behaviour in relation to that problem from an Islamic perspective”. Dengan demikian, menurut Kursyid Ahmad, ekonomi syari'âh adalah sebuah usaha sistematis untuk memahami masalah-masalah ekonomi dan tingkah laku manusia secara relasional dalam perspektif Islam ${ }^{26}$. Sementara itu, melengkapi beberapa definisi sebelumnya, MA. Mannan menjelaskan: "Islamic economics is a social science which studies the economics problems of a people imbued with the values of Islam".

Terangnya, ekonomi syari'âh merupakan ilmu pengetahuan sosial yang mempelajari masalah-masalah ekonomi masyarakat yang diilhami oleh nilai-nilai Islam. $^{27}$ Ekonomi syari’âh, yang dituju bukan hanya individu sebagai sosial,melainkan manusia dengan bakat religius manusia. Ini beda dengan ekonomi modern yang hanya menuju pada manusia sebagai makhluq sosial. Demikian halnya dalam cara menyelesaikan masalah ekonomi: jika ekonomi

24 Muhammad Akram Khan, Ajaran Nabi Muhammad Saw tentang Ekonomi, terj Rifyal Ka'bah MA, (Jakarta: PT. Bank Muamalat Indonesia dan Institute of Policy Studies Islamabad, 1997), h. 3-4.

25 Nurul Huda et.al, Ekonomi Makro Islam: Pendekatan Teoritis. (Kencana: Jakarta, 2008), h. 2.

26 Ibid.

27 Ibid 
syari'âh dikendalikan oleh nilai-nilai dasar Islam, maka ekonomi modern sangat dikuasai oleh kepentingan diri individu. ${ }^{28}$

M. Abdul Mannan memberikan definisi ilmu ekonomi Islam sebagai ilmu pengetahuan sosial yang mempelajari masalah-masalah ekonomi kerakyatan yang diilhami oleh nilai-nilai dan ajaran Islam. $^{29}$ Syed Nawab Husein Naqvi menegaskan ide sentral yang membatasi ilmu ekonomi Islam dan yang menempatkannya berbeda dengan ilmu ekonomi positif adalah nilai-nilai etik/agama secara eksplisit dimasukkan dalam frame work analisis ekonomi secara terpadu. Oleh karena itu, ilmu ekonomi Islam merupakan upaya validitas ide filosofis (normatif) yang diaplikasikan dan dipadukan dengan klaim validitas objektif (empiris). ${ }^{30}$

Dari pengertian ekonomi Islam di atas, dapat dijelaskan bahwa kajian dan pembahasan ekonomi Islam berdimensi kerakyatan dengan sistem yang dibangun merupakan representasi dari ajaran dan nilai-nilai Islam. Adapun kepentingan atau tujuan dari sistem ekonomi Islam merupakan suatu bentuk "ijtihad" dari penerjemahan ajaran agama (maqâshid syari'ah) pada wilayah normatif agar dapat dipraktikkan menjadi sistem yang aplikatif pada wilayah sosial (kerakyatan).

Aplikasi ajaran agama dalam bidang ekonomi Islam paling banyak pada lembaga perbankkan yang telah berkembang cukup signifikan dalam 3 tahun terakhir dengan indikator market share terhadap perbankan konvensional telah mencapai $1,8 \%$ dan BI mempunyai target $5 \%$ pada tahun 2010 .

\section{Keadilan Ekonomi ala Ekonomi Syari’âh}

Ekonomi syari'âh adalah sistem ekonomi yang berdasar pada al-Qur'an dan al-Hadits yang bertujuan untuk memenuhi kebutuhan manusia di dunia maupun di akhirat. Pada aras pemenuhan kebutuhan manusia, ekonomi syari'âh

28 MN Harisudin, Ekonomi Shariah Dan Ketidakadilan Kapitalisme Global, ISLAMICA, Vol. 5, No. 2, Maret 2011, h. 235-236.

29 M. Abdul Mannan, Ekonomi Islam, Teori, dan Praktik, Terj. Nastangin, (Yogyakarta: Dana Bhakti Prima Yasa, 1997), h. 19.

30 Syed Nawab Haedar Naqvi, Menggagas Ilmu Ekonomi Islam, Terj. M. Saiful Anam dan M. Ufuqul Mubin, (Yogyakarta: Pustaka Pelajar, 2003), h. 19. 
sejatinya sama dengan ekonomi konvensional. ${ }^{31}$ Bedanya, ekonomi syari'âh tidak hanya mendasarkan kebutuhan manusia di dunia, namun juga di akhirat. Dimensi dunia akhirat inilah yang membedakan dengan ekonomi konvensional.

Setidaknya, ada tiga asas filsafat ekonomi syari'âh. ${ }^{32}$ Pertama, semua yang ada di alam semesta ini adalah milik Allah SWT. Manusia hanyalah khalifah yang memegang amanah dari Allah SWT untuk menggunakan milik-Nya. Sehingga segala sesuatu harus tunduk pada Allah Sang Pencipta dan pemilik. (QS: Al-Najm: 31). Kedua, untuk dapat melaksanakan tugasnya sebagai khalifah Allah, manusia wajib tolong-menolong dan saling membantu dalam melaksanakan kegiatan ekonomi yang bertujuan untuk beribadah pada Allah. Ketiga, beriman pada hari kiamat yang merupakan asas penting dalam sistem ekonomi shariah. Dengan keyakinan seperti ini, tingkah laku manusia akan dapat terkendali. Sebab ia sadar bahwa semua perbuatannya akan dimintai pertanggung jawabannya kelak oleh Allah SWT. ${ }^{33}$ Di bawah tiga filsafat pokok ini, ada beberapa nilai dalam ekonomi shariah, sebagaimana berikut:

1. Nilai dasar kepemilikan, menurut sistem ekonomi syari'âh:

a. Kepemilikan bukan penguasaan mutlak atas sumber-sumber ekonomi, tetapi setiap orang atau badan dituntut kemampuannya untuk memanfaatkan sumber-sumber ekonomi tersebut.

b. Lama kepemilikan manusia atas sesuatu benda terbatas pada lamanya manusia hidup di dunia.

c. Sumber daya yang menyangkut kepentingan umum, seperti air, rumput, api, minyak, gas bumi, dan kebutuhan pokok lainnya harus menjadi milik umum.

31 Timur Kuran menyebut tiga hal yang membedakan ekonomi shariah dengan yang lainnya: norma-norma, zakat dan tidak ada bunga. Lihat, Timur Kuran, "The Economic System in Contemporary Islamic Thought", dalam Jomo K. S. (Ed.). Islamic Economic Alternatives, Critical Perspectives and ew Direction. (Selangor Malaysia: Ikraq, 1993), p. 9.

${ }^{32}$ MN Harisudin, Ekonomi Shariah Dan Ketidakadilan Kapitalisme Global, ISLAMICA, Vol. 5, No. 2, Maret 2011, h. 240-242.

33 Nurul Huda et.al, Ekonomi Makro Islam: Pendekatan Teoritis. (Kencana: Jakarta, 2008), h. 34. 
2. Keseimbangan yang terwujud pada kesederhanaan, hemat dan menjauhi sikap pemborosan. (QS. Al-Furqan: 67).

3. Keadilan dalam kehidupan ekonomi seperti proses distribusi, produksi, konsumsi dan lain sebagainya. Keadilan juga diwujudkan dalam mengalokasikan kegiatan ekonomi tertentu bagi orang yang tidak mampu memasuki pasar melalui zakat, infak, dan hibah ${ }^{34}$.

Ketiga nilai di atas, pada tahapan selanjutnya, menjadi inti dalam berbagai terapan ekonomi syari'âh. Bank syari'âh misalnya. Dalam bank ini, dikembangkan sistem yang berkeadilan yang disebut dengan profit sharing (bagi hasil). Jika sistem kapitalisme menggunakan piranti bunga sebagai suatu yang built in dalam bank konvensional, maka bank syari'âh menggesernya dengan sistem bagi hasil. Sistem bagi hasil merupakan bentuk eksplisit anti-riba yang sejak awal ditentang oleh bank syari'âh. Karena, Islam secara tegas, melarang umatnya untuk memberi, mengambil atau memakan riba ${ }^{35}$. Dalam bunga bank konvensional, pemilik modal adalah orang yang sangat diuntungkan karena dalam kondisi apapun ia tetap akan memperoleh bunga tanpa usaha dan berkeringat ${ }^{36}$.

Seorang pengusaha yang mendepositokan uang 100 milyar misalnya, seumur hidup tanpa bekerja, ia sudah mendapatkan uang yang mengucur deras dari bank tempat ia menaruh uangnya. Bandingkan dengan para tukang becak yang seharian berpeluh keringat hanya mendapat uang Rp. 20.000,- kalau nasib untung. Padahal, sang tukang becak juga bisa tidak mendapatkan apa-apa seharian bekerja.

Islam mengganti sistem bunga yang menindas dengan profit sharing. Profit sharing (bagi hasil) yang diterapkan dalam ekonomi syari'ah jelas lebih berkeadilan. Bagi deposan, untung yang didapat adalah benar-benar hasil untung pekerja yang diberi modal. Sementara, bagi peminjam (yang juga pekerja) tidak

34 Ibid., 4

35 Sudin Haron, Prinsip dan Operasi Perbankan Islam, (Kuala Lumpur: Berita Publishing, 1996), Bandingkan dengan Analisis Kritis Abdullah Saeed tentang Bunga dan Bank Islam. Lihat, Abdullah Saeed, Islamic Banking and Interest, A Studi of The Prohibition of Riba and Its Contemporary Interpretation (Netherland: Studies in Islamic Law and Society, 1996), h. 1739.

36 Ibid. 
merasa terbebani dengan bunga yang tinggi. Karena ia hanya membayarkan sejumlah untung yang ia dapat dari bekerja. Kalau untung banyak, ia akan membayar banyak bagi hasilnya. Kalau untung sedikit, ia pun akan membayar sedikit bagi hasilnya.

Dalam hal jaminan sosial, ekonomi shariah secara de facto mengajukan zakat sebagai piranti pengentasan kemiskinan. Namun, zakat, dalam cita ideal ekonomi syari'âh sesungguhnya diangankan bukan hanya sebagai pelindung kaum papa dari kelaparan, tetapi ia juga dicitakan sebagai media pemberdayaan ekonomi ummat. Oleh karenanya, Nabi Muhammad SAW tidak hanya memberikan teladan zakat karitatif yang konsumtif, namun beliau juga mendorong pelaksanaan zakat produktif yang filantropis dan memberdayakan tersebut. 


\section{Kesimpulan}

Konsep pertumbuhan ekonomi dalam Islam berbeda dengan konsep pertumbuhan ekonomi kepitalisme yang selalu menggunakan indikator PDB (Produk Dosmetik Bruto) dan perkapita. Dalam Islam, pertumbuhan harus seiring dengan pemerataan. Tujuan kegiatan ekonomi, bukanlah meningkatkan pertumbuhan sebagaimana dalam konsep ekonomi kapitalisme. Tujuan ekonomi Islam lebih memprioritaskan pengentasan kemiskinan dan pengurangan pengangguran.

Penegakkan keadilan sosio-ekonomi Islami dilandasi oleh rasa persaudaraan (ukhuwah), saling mencintai (mahabbah), bahu-membahu (takaful) dan saling tolong-menolong (ta'awun), baik antara si kaya dan si miskin maupun antara penguasa dan rakyat.

Selanjutnya, dalam rangka mewujudkan cita-cita keadilan sosial ekonomi, Islam secara tegas melarang konsentrasi asset kekayaan pada sekelompok tertentu dan menawarkan konsep zakat, infaq, shadaqah, waqaf dan institusi lainnya, seperti pajak, jizyah, dan sebagainya. 


\section{DAFTAR PUSTAKA}

Abdul Baqi, Muhammad Fu'ad, al-Mu'jam al-Mufahras li alfazd Al-Qur'an alKarim, Mesir: Dar al-Fikr, 1981.

al-'Assal, Ahmad Muhammad dan Fathi Ahmad Abdul Karim, Sistem, Prinsip, dan Tujuan Ekonomi Islam, Terj. Imam Saefudin, Bandung: Pustaka Setia, 1999.

Harisudin, MN, Ekonomi Shariah dan Ketidakadilan Kapitalisme Global, ISLAMICA, Vol. 5, No. 2, Maret 2011.

Haron, Sudin, Prinsip dan Operasi Perbankan Islam, (Kuala Lumpur: Berita Publishing, 1996.

http://isjd.pdii.lipi.go.id/admin/jurnal/81081732.pdf Peran Lembaga Keuangan Publik Islam, diakses 23 Januari 2013.

http://www.hayatulislam.net : 2322 Januari 2013.

Huda, Nurul et.al, Ekonomi Makro Islam: Pendekatan Teoritis. Kencana: Jakarta, 2008.

Kahduri, Majid, The Islamic Conception of Justice, 1984.

Khan, Muhammad Akram, Ajaran Nabi Muhammad Saw tentang Ekonomi, terj Rifyal Ka'bah MA, Jakarta: PT. Bank Muamalat Indonesia dan Institute of Policy Studies Islamabad, 1997.

M. Abdul Mannan, Ekonomi Islam, Teori, dan Praktik, Terj. Nastangin (Yogyakarta: Dana Bhakti Prima Yasa, 1997), hal. 19.

Naqvi, Syed Nawab Haedar, Menggagas Ilmu Ekonomi Islam, Terj. M. Saiful Anam dan M. Ufuqul Mubin, Yogyakarta: Pustaka Pelajar, 2003.

Nuruddin, Amiur, Konsep Keadilan Dalam Al-Qur'an dan Implikasinya Pada Tanggung Jawab Moral, Disertasi pada Program Pascasarjana IAIN Sunan Kalijaga, Yogyakarta, 1994.

Rahman, Afzalur, Ecnomic Doktrines of Islam, terj. Soeroyo et al. Yogyakarta: Dhana Bakti Wakaf, 1995.

Rahman, Fazlur, Islam and Modernity, Transformation of Intellectual Tradition, Chicago: The University of Chicago Press, 1982.

Ruslan Abdul Ghofur Noor, Kebijakan Distribusi Ekonomi Islam Dalam Membangun Keadilan Ekonomi Indonesia, ISLAMICA, Vol. 6, No. 2, Maret 2012.

Saeed, Abdullah, Islamic Banking and Interest, A Studi of The Prohibition of Riba and Its Contemporary Interpretation, Netherland: Studies in Islamic Law and Society, 1996. 
Shadr, Muhammad Baqir Ekonomi Islam : Khayalan atau Kenyataan?, Yayasan Muthahhari

Shihab, M. Quraish Tafsir al-Mishbah, Vol. 14, Jakarta: Lentera Hati, 2002. 